\title{
Tingkat Ketersediaan Faktor-Faktor Produksi \\ di Tingkat Petani dan Pengaruhnya Terhadap Produksi dan Pendapatan \\ Pada Usahatani Jagung (Zea mays L.) \\ (Kasus di Desa Ngrancang, Kecamatan Tambakrejo, Kabupaten Bojonegoro)
}

\section{Level of Production Factors Availability at Farmers Level and The Effect On Production and Income of Corn Farming (Zea mays L.) (Case in Ngrancang Village, Tambakrejo Subdistrict, Bojonegoro Regency)}

\author{
Indriyati $^{{ }^{*}}$, Moch. Muslich Mustadjab ${ }^{2}$ \\ Jurusan Sosial Ekonomi, Fakultas Pertanian, Agribisnis, Universitas Brawijaya, Jl. Veteran Malang \\ 65145, Jawa Timur, Indonesia
}

Diterima: 4 Agustus 2016; Direvisi: 20 November 2016; Disetujui: 30 Desember 2016

\begin{abstract}
ABSTRAK
Tujuan dari penelitian ini adalah menganalisis masalah untuk memperoleh masukan dalam upaya peningkatan pendapatan. Jagung merupakan salah satu komoditas pangan yang penting dan terkait dengan industri besar. Penelitian ini dilakukan secara purposive dengan metode pengambilan contoh yaitu Stratified Random Sampling, sehingga didapatkan responden 38 sampel. Metode analisis data yang digunakan adalah analisis ketersediaan faktor produksi, analisis usahatani, dan analisis fungsi respon produksi dan pendapatan, dan analisis efisiensi alokatif. Hasil analisis menunjukan ketersediaan faktor produksi sudah cukup tersedia dan penggunaan faktor produksi usahatani jagung masih belum efisien. Sehingga produksi yang dihasilkan masih rendah, begitupula dengan tingkat pendapatan petani.
\end{abstract}

Kata Kunci: jagung; ketersediaan; faktor produksi; produksi; pendapatan

\begin{abstract}
The aim of this research is analyze the problems to obtain input in an effort to increase the income. Corn is one of the essential food commodities and associated with large industries. This research uses purposive with stratified random sampling method, then determines respondent by 38 samples. Data analysis method used was production factors availability analysis, farming analysis, and the response function of production and income analysis and allocative efficiency analysis. Results of the analysis showed that the availability of production factors is available enough and the use of production factors in corn farming is still not efficient. So that production result is still low, nor with the level of farmers income.
\end{abstract}

Keywords : corn; availability; production factors; production; income

\section{Pendahuluan}

Pembangunan pertanian di Indonesia dapat dilakukan dengan meningkatkan hasil produksi pertanian. Peningkatan hasil produksi pertanian dilakukan dengan usaha ekstensifikasi, intensifikasi dan diversifikasi (Mubyarto, 1994). Pertanian di Indonesia terdiri dari beberapa jenis komoditas seperti komoditas tanaman pangan, komoditas tanaman perkebunan, dan komoditas tanaman hortikultura. Komoditas pangan menjadi

\footnotetext{
*) Penulis Korespondensi

E-mail: indriyati@gmail.com
}

tanaman yang banyak dikembangkan di Indonesia. Hal ini dikarenakan tanaman pangan dianggap lebih cepat untuk dipanen dan lebih menguntungkan. Salah satu tanaman pangan yang cukup banyak dibudidayakan yaitu komoditas jagung.

Jagung merupakan salah satu komoditas pangan yang penting dan terkait dengan industri besar. Jagung tidak hanya dikonsumsi untuk sayur melainkan dapat diolah menjadi makanan. Selain itu jagung digunakan untuk bahan utama industri pakan ternak (Warsana, 2007). Menurut Badan Pengawas Perdagangan Berjangka Komoditi (2012), menyebutkan bahwa kebutuhan 
jagung untuk pakan ternak di Indonesia diperkirakan mencapai sebesar 7 juta ton per tahun. Kondisi ini membuat jagung memiliki prospek yang sangat menjanjikan untuk dikembangkan.

Kecamatan Tambakrejo merupakan salah satu penghasil jagung terbesar di Bojonegoro. Produksi Jagung di Kecamatan Tambakrejo pada tahun 2013 yaitu sebesar 22.707,67 ton (BPS Bojonegoro, 2014). Desa Ngrancang merupakan salah satu desa di Kecamatan Tambakrejo yang menghasilkan produksi jagung terbesar di kecamatan tersebut dengan luas lahan yang ditanami pada tahun 2013 yaitu sebesar $179 \mathrm{Ha}$. Dengan lahan yang cukup luas Desa Ngrancang dilakukan pengembangan usahatani jagung dengan melakukan penanaman jagung dilahan hutan agar mendapatkan hasil panen jagung lebih tinggi. Untuk memperoleh hasil panen yang tinggi dibutuhkan faktor produksi seperti lahan, benih, pupuk, dan tenaga kerja.

Desa Ngrancang tidak selalu mendapatkan faktor produksi yang digunakan dengan mudah. Bahkan kadangkala terjadi kelangkaan pupuk kimia. Apabila pengiriman pupuk tidak tepat waktu, petani mengalami kesulitan untuk mencari pupuk kimia. Penggunaan faktor produksi yang efisien dan kemudahan memperoleh faktor produksi akan memperlancar kegiatan usahatani.

Berdasarkan uraian diatas, pada penelitian ini dirumuskan sebagai "sejauh mana tingkat ketersediaan faktor-faktor produksi berpengaruh terhadap produksi dan pendapatan usahatani”. Tujuan penelitian ini adalah (1) Menganalisis tingkat ketersediaan faktor produksi usahatani jagung di Desa Ngrancang Kecamatan Tambakrejo Kabupaten Bojonegoro (2) Menganalisis tingkat produksi dan pendapatan usahatani jagung di Desa Ngrancang Kecamatan Tambakrejo Kabupaten Bojonegoro

Menganalisis faktor yang berpengaruh terhadap produksi dan pendapatan usahatani jagung di Desa Ngrancang Kecamatan Tambakrejo Kabupaten Bojonegoro (4) Menganalisis tingkat efisiensi penggunaan faktor-faktor produksi pada usahatani jagung di Desa Ngrancang Kecamatan Tambakrejo Kabupaten Bojonegoro.

\section{Metode Penelitian}

Penelitian ini dilaksanakan di Desa Ngrancang, Kecamatan Tambakrejo, Kabupaten Bojonegoro. Penentuan lokasi penelitian dilakukan secara purposive, sesuai dengan tujuan penelitian dengan pertimbangan bahwa Desa
Ngrancang merupakan salah satu daerah penghasil jagung terbesar di Kecamatan Tambakrejo dan desa tersebut memiliki kesesuaian lahan yang sesuai untuk pengembangan komoditas jagung. Pengambilan sampel dengan cara metode Stratified Random Sampling menggunakan rumus Parel, et.al. (1973). Berdasarkan rumus tersebut diperoleh jumlah sampel responden sebanyak 38 sampel. Dalam penelitian ini metode analisis data yang digunakan sesaui dengan tujuan penelitian adalah sebagai berikut:

\subsection{Analisis Tingkat Ketersediaan Faktor Produksi Usahatani Jagung}

Dalam penelitian ini tingkat ketersediaan faktor produksi usahatani jagung di ukur dengan memberikan skor pada jawaban petani terhadap pertanyaan-pertanyaan untuk indikator-indikator ketersediaan yaitu ketersediaan benih, ketersediaan pupuk, dan ketersediaan tenaga kerja.

Kemudian skor pada masing-masing indikator pada variabel ketersediaan dijumlahkan. Total skor menunjukan tingkat ketersediaan faktor produksi yang dilakukan oleh petani responden, yang dikelompokan menjadi kategori cukup tersedia dan kurang tersedia dengan ketentuan sebagai berikut:

a. Tingkat ketersediaan faktor produksi yang kurang tersedia, apabila total skor jawaban petani respoden terhadap indikatorindikator variabel ketersediaan benih, pupuk dan tenaga kerja adalah $<12$.

b. Tingkat ketersediaan faktor produksi yang cukup tersedia, apabila total skor jawaban petani respoden terhadap indikatorindikator variabel ketersediaan benih, pupuk dan tenaga kerja adalah $>12$.

\subsection{Analisis Tingkat Produksi dan Pendapatan Usahatani Jagung}

Analisis tingkat produksi dan pendapatan dilakukan dengan membandingkan rata-rata tingkat produksi dan pendapatan di daerah penelitian dengan rata-rata produksi dan pendapatan di daerah Bojonegoro. Sehingga akan diperoleh kesimpulan hasil produksi dan pendapatan di daerah penelitian lebih rendah atau lebih tinggi dibandingkan daerah Bojonegoro. 


\subsection{Analisis Faktor yang Berpengaruh Pada Produksi Terhadap Produksi dan Pendapatan Usahatani Jagung}

Analisis faktor yang berpengaruh terhadap produksi dan pendapatan usahatani jagung dilakukan dengan menggunakan fungsi respon produksi dan fungsi respon pendapatan.

a. Fungsi Respon Produksi

Fungsi respon produksi yang dipakai adalah fungsi Cobb-Douglas sebagai berikut:

$Y=\mathrm{aX}_{1}{ }^{\beta 1} \mathrm{X}_{2}{ }^{\beta 2} \mathrm{X}_{3}{ }^{\beta 3} \mathrm{X}_{4}{ }^{\beta 4} \mathrm{X}_{5}{ }^{\beta 5} \mathrm{X}_{6}{ }^{\beta 6} e^{u} \ldots .(1)$

Agar mempermudah pendugaan hasil

fungsi, fungsi Cobb-Douglas ditransformasikan menjadi bentuk linear sebagai berikut:

$\operatorname{Ln} Y=\operatorname{Ln} \beta_{0}+\beta_{1} \operatorname{Ln} \mathrm{X}_{1}+\beta_{2} \operatorname{Ln} \mathrm{X}_{2}+$

$$
\begin{aligned}
& \beta_{3} \operatorname{Ln} \mathrm{X}_{3}+\beta_{4} \operatorname{Ln} \mathrm{X}_{4}+\beta_{5} \operatorname{Ln} \mathrm{X}_{5}+ \\
& \beta_{6} \operatorname{Ln} \mathrm{X}_{6}+u \ldots \ldots \ldots \ldots \ldots \ldots \ldots \ldots \ldots \ldots \ldots \ldots \ldots \ldots \ldots
\end{aligned}
$$

Dimana :

$\mathrm{Y} \quad=$ Jumlah Produksi jagung pada musim tanam Nopember 2014-Februari 2015 $(\mathrm{Kg})$

$\mathrm{X}_{1} \quad=$ Jumlah benih yang digunakan dalam usahatani jagung pada musim tanam Nopember 2014-Februari 2015 (Kg)

$\mathrm{X}_{2} \quad=$ Jumlah pupuk kimia yang digunakan dalam usahatani jagung pada musim tanam Nopember 2014-Februari 2015 $(\mathrm{Kg})$

$\mathrm{X}_{3} \quad=$ Jumlah tenaga kerja yang digunakan dalam usahatani jagung pada musim tanam Nopember 2014-Februari 2015 (HKSP)

$\mathrm{X}_{4}=$ Tingkat Ketersediaan Benih (Total Skor)

$\mathrm{X}_{5} \quad=$ Tingkat Ketersediaan Pupuk Kimia (Total Skor)

$\mathrm{X}_{6}=$ Tingkat Ketersediaan Tenaga Kerja (Total Skor)

a $\quad=$ Konstanta

$\mathrm{b}_{1, \ldots} \mathrm{b}_{6}=$ Elastisitas pendapatan

$\mathrm{u} \quad=$ Galat (kesalahan)

b. Fungsi Respon Pendapatan

Fungsi respon pendapatan yang dipakai dirumuskan dengan persamaan sebagai berikut:

$Y=a+b_{1} X_{1}+b_{2} X_{2}+b_{3} X_{3}+b_{4} X_{4}+$

$b_{5} X_{5}+b_{6} X_{6}+b_{7} X_{7}+\mathrm{u}$

Dimana:

$\mathrm{Y} \quad=$ Pendapatan usahatani jagung pada musim tanam Nopember 2014Februari 2015 (Rp)
$\mathrm{X}_{1}=$ Penerimaan usahatani jagung pada musim tanam Nopember 2014Februari 2015 (Rp)

$\mathrm{X}_{2}=$ Biaya Benih pada musim tanam Nopember 2014-Februari 2015 (Rp)

$\mathrm{X}_{3} \quad=$ Biaya Pupuk kimia pada musim tanam Nopember 2014-Februari 2015 (Rp)

$\mathrm{X}_{4} \quad=$ Biaya Tenaga Kerja pada musim tanam Nopember 2014-Februari 2015 (Rp)

$\mathrm{X}_{5}=$ Tingkat Ketersediaan Benih (Total Skor)

$\mathrm{X}_{6}=$ Tingkat Ketersediaan Pupuk Kimia (Total Skor)

$\mathrm{X}_{7}=$ Tingkat Ketersediaan Tenaga Kerja (Total Skor)

a $\quad=$ Konstanta

$\mathrm{b}_{1, \ldots} \mathrm{b}_{7}=$ Elastisitas pendapatan

$\mathrm{u} \quad=$ Galat (kesalahan)

2.4. Analisis Tingkat Efisiensi Penggunaan Faktor-faktor Produksi Usahatani Jagung

Dalam penelitian ini analisis efisiensi penggunaan faktor produksi dilakukan dengan menggunakan analisis fungsi produksi cobbdouglas, dengan model persamaan sebagai berikut.

$\operatorname{Ln} Y=\operatorname{Ln} \beta_{0}+\beta_{1} \operatorname{Ln} \mathrm{X}_{1}+\beta_{2} \operatorname{Ln} \mathrm{X}_{2}+$ $\beta_{3} \operatorname{Ln} \mathrm{X}_{3}+u$

Dimana:

$\mathrm{Y}=$ Jumlah Produksi jagung pada musim tanam November 2014-Februari 2015 $(\mathrm{Kg})$

$X_{1}=$ Jumlah benih yang digunakan dalam usahatani jagung pada musim tanam November 2014-Februari 2015 (Kg)

$X_{2}=$ Jumlah pupuk kimia yang digunakan dalam usahatani jagung pada musim tanam November 2014-Februari 2015 $(\mathrm{Kg})$

$X_{3}=$ Jumlah tenaga kerja yang digunakan dalam usahatani jagung pada musim tanam November 2014-Februari 2015 (HKSP)

Kemudian menghitung tingkat efisiensinya dengan cara membandingkan nilai NPMx dengan Px seperti rumus sebagai berikut.

NPMx $=b i \frac{Y}{X i} P y$

$\mathrm{PXi}=$ harga input $\mathrm{X}$ ke $\mathrm{i}$

Tingkat efisiensi alokatif $=\frac{N P M x i}{P x i}$ 


\begin{tabular}{|c|c|}
\hline Dimana: & \\
\hline NPMxi & $\begin{array}{l}=\text { Nilai produkk marjinal faktor } \\
\text { produksi ke-i }\end{array}$ \\
\hline bi & $=$ Elatisistas produksi \\
\hline $\mathrm{Xi}$ & $=$ Input produksi $(\mathrm{X}) \mathrm{ke} \mathrm{i}$ \\
\hline Y & $=$ Rata-rata produksi jagung $(\mathrm{Kg})$ \\
\hline Pxi & $\begin{array}{l}\text { = Rata-rata harga faktor produksi } \\
\text { jagung ke-i (Rp) }\end{array}$ \\
\hline Py & $\begin{array}{l}=\text { Rata-rata harga satuan hasil } \\
\text { produksi jagung (Rp) }\end{array}$ \\
\hline
\end{tabular}

Semakin mendekati nilai $\frac{N P M x i}{P x i}$ berarti semakin efisien penggunaan input $\mathrm{X}$ nya, $\frac{N P M x i}{P x i}$ yang paling efisien adalah apabila nilainya sama dengan 1 atau NPMx = Px. Hal ini dikarenakan pada saat itu keuntungan akan maksimum.

\section{Hasil dan Pembahasan}

\subsection{Analisis Tingkat Ketersediaan Faktor Produksi Usahatani Jagung}

Berikut ini tingkat ketersediaan yang dilakukan oleh petani responden pada Tabel 1 .

Tabel 1. Tingkat Ketersediaan Faktor Produksi Petani Resonden

\begin{tabular}{|c|c|c|c|}
\hline No. & Variabel & $\begin{array}{c}\text { Rata-rata } \\
\text { Total Skor }\end{array}$ & Kategori \\
\hline 1. & $\begin{array}{l}\text { Ketersediaan } \\
\text { Benih }\end{array}$ & 15 & $\begin{array}{l}\text { Cukup } \\
\text { Tersedia }\end{array}$ \\
\hline 2. & $\begin{array}{l}\text { Ketersediaan } \\
\text { Pupuk Kimia }\end{array}$ & 14 & $\begin{array}{l}\text { Cukup } \\
\text { Tersedia }\end{array}$ \\
\hline 3. & $\begin{array}{l}\text { Ketersediaan } \\
\text { Tenaga Kerja }\end{array}$ & 14 & $\begin{array}{l}\text { Cukup } \\
\text { Tersedia }\end{array}$ \\
\hline
\end{tabular}

a. Ketersediaan Benih

Tingkat ketersediaan benih menurut jawaban petani responden tergolong dalam kategori cukup tersedia dengan rata-rata skornya adalah 15. Ketersediaan benih ini dilihat dari rata-rata total skor indikator ketersediaan benih yaitu kemudahan memperoleh benih, harga benih, keterjangkauan tempat penjualan benih, dan kontinyuitas tersedianya benih di tempat penjualan benih. Untuk memperoleh benih, petani membeli dari toko pertanian yang berada di luar desa Ngrancang yang jaraknya tidak terlalu jauh dari desa tersebut.

\section{b. Ketersediaaan pupuk kimia}

Ketersediaan pupuk kimia di daerah penelitian tergolong dalam kategori cukup tersedia dengan rata-rata toal skor tingkat ketersediaan pupuk kimia adalah 14. Ketersediaan pupuk kimia dilihat dari jawaban petani terhadap indikator ketersediaan pupuk kimia yaitu harga pupuk kimia, subsidi pupuk kimia dari pemerintah, keterjangkauan tempat penjualan pupuk dan kontinyuitas tersedianya pupuk kimia di kios penjualan pupuk. Pupuk kimia diperoleh dari kios resmi, gapoktan dan kelompok tani yang ada di daerah penelitian, sehingga petani akan lebih mudah untuk mencari pupuk.

\section{c. Ketersediaan Tenaga Kerja \\ Tingkat ketersediaan tenaga kerja menurut} jawaban petani responden tergolong dalam kategori cukup tersedia dengan rata-rata total skor adalah 14. Tenaga kerja yang ada di daerah penelitian lebih banyak berasal dari dalam keluarga sendiri, Di daerah penelitian terdapat tenaga kerja musiman pada saat musim tanam dan musim panen jagung tiba. Selain itu, upah untuk tenaga kerja di daerah penelitian yang cukup mahal, sehingga banyak orang yang awalnya tidak bekerja di pertanian pada saat musim tanam dan musim panen jagung tiba ikut bekerja di lahan untuk memperoleh pendapatan.

\subsection{Analisis Tingkat Produksi dan Pendapatan Usahatani Jagung}

Hasil analisis tingkat produksi dan pendapatan usahatani jagung disajikan pada Tabel 2.

Tabel 2. Hasil Analisis Usahatani Jagung di Desa Ngrancang

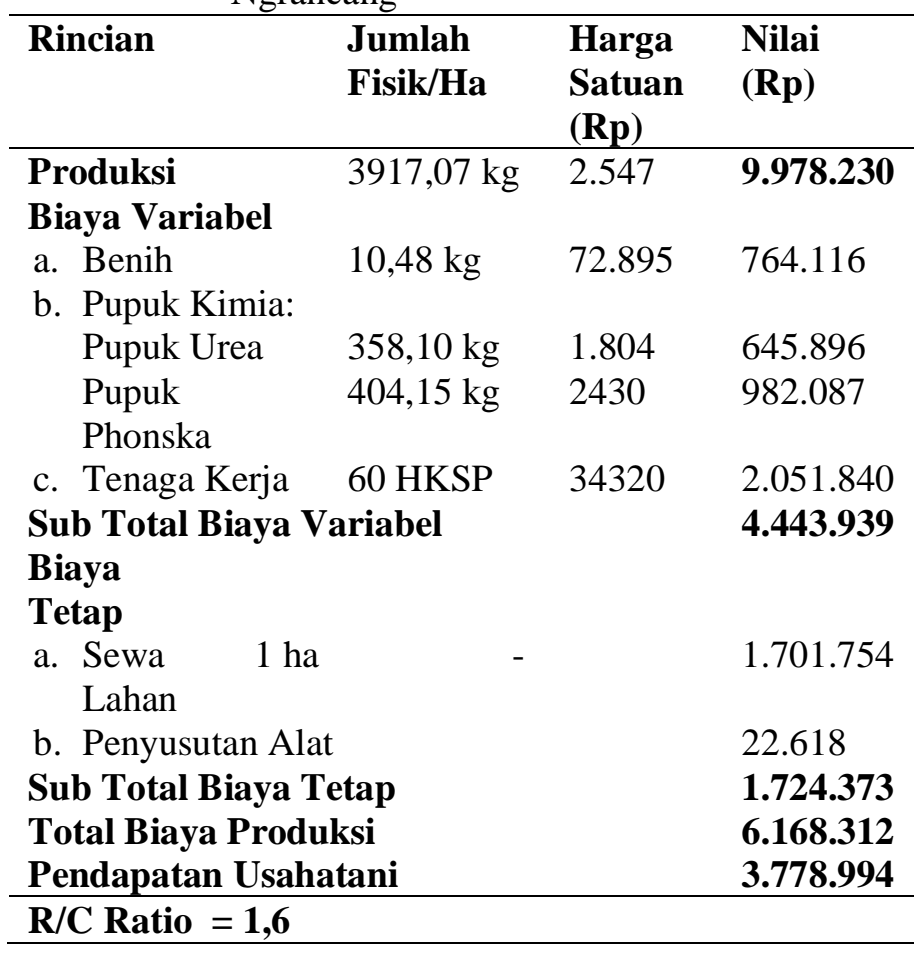


Menunjukan bahwa rata-rata tingkat produksi usahatani jagung di Desa Ngrancang, Kecamatan Tambakrejo, Kabupaten Bojonegoro adalah $3917,07 \mathrm{~kg} \mathrm{~kg} / \mathrm{ha}$ atau sebesar 3,9 ton/ ha. Hasil tersebut masih rendah dibandingkan dengan produktivitas jagung di Kabupaten Bojonegoro sebesar 4,23 ton/ha. Hal ini dikarenakan penggunaan faktor produksi yang belum efisien sehingga produksi yang diperoleh dari usahatani jagung masih rendah. Untuk meningkatkan produksi jagung dapat dilakukan dengan menambah faktor produksi yang belum efisien untuk usahatani jagung. Sedangkan rata-rata tingkat pendapatan di daerah penelitian sebesar Rp 3.778.994/ha.

\subsection{Analisis Faktor yang Berpengaruh Terhadap Produksi dan Pendapatan Usahatani Jagung}

Analisis faktor-faktor yang berpengaruh terhadap produksi dilakukan dengan menggunakan model fungsi respon produksi cobb-douglas dan faktor yang berpengaruh terhadap pendapatan dilakukan dengan menggunakan model linier berganda.

\subsubsection{Analisis Faktor-faktor yang Berpengaruh Pada Produksi Usahatani Jagung}

Hasil analisis regresi fungsi respon produksi cobb-douglas disajikan pada Tabel 3.

Tabel 3. Hasil Uji Regresi Fungsi Respon Produksi

\begin{tabular}{|c|c|c|c|}
\hline Variabel & $\begin{array}{l}\text { Koefisien } \\
\text { Regresi }\end{array}$ & $\mathbf{t}_{\text {hitung }}$ & Sig. \\
\hline (Constant) & 4,584 & 7,269 & \\
\hline Ln_Benih $(\mathrm{Kg} / \mathrm{Ha})$ & $0,858^{*}$ & 6,247 & 0,000 \\
\hline $\begin{array}{l}\text { Ln_Pupuk Kimia } \\
(\mathrm{Kg} / \mathrm{Ha})\end{array}$ & 0,030 & 0,511 & 0,613 \\
\hline $\begin{array}{l}\text { Ln_Tenaga Kerja } \\
\text { (HKSP/Ha) }\end{array}$ & $0,185 * * *$ & 1,892 & 0,068 \\
\hline $\begin{array}{l}\text { Ln_Tingkat } \\
\text { Ketersediaan Benih } \\
\text { (Skor) }\end{array}$ & 0,021 & 0,199 & 0,843 \\
\hline $\begin{array}{l}\text { Ln_Tingkat } \\
\text { Ketersediaan Pupuk } \\
\text { (Skor) }\end{array}$ & 0,020 & 0,147 & 0,884 \\
\hline $\begin{array}{l}\text { Ln_Tingkat } \\
\text { Ketersediaan Tenaga } \\
\text { Kerja (Skor) }\end{array}$ & 0,236 & 1,312 & 0,199 \\
\hline $\begin{array}{l}\mathrm{F}_{\text {hitung }}=11,789 \\
\mathrm{R}^{2}=0,695\end{array}$ & & & \\
\hline
\end{tabular}

http://www.habitat.ub.ac.id, ISSN: 0853-5167 (p); 2338-2007 (e)
Keterangan:

$\mathrm{n}=38$

Variabel dependen $=$ Produksi $(\mathrm{Kg} / \mathrm{Ha})$

$*=$ Nyata pada $\alpha 0,01 \quad * *=$ Nyata pada $\alpha 0,05$

$* * *=$ Nyata pada $\alpha 0,1$

$\mathrm{t}$ tabel $\alpha 0,01=2,378 ; \mathrm{t}$ tabel $\alpha 0,05=2,037 ; \mathrm{t}$ tabel $\alpha 0,1=1,694$

$\mathrm{F}$ tabel $\alpha 0,01=3,45 ; \mathrm{F}$ tabel $\alpha 0,05=2,40 ; \mathrm{F}$ tabel $\alpha 0,1=2,83 ; \mathrm{dfl}=6 ; \mathrm{df} 2=31$

Dari hasil uji asumsi klasik dapat disimpulkan bahwa data untuk model regresi yang dipakai tidak terjadi penyimpangan terhadap asumsi klasik. Setelah uji asumsi klasik, dilanjutkan uji model menggunakan uji $\mathrm{F}$, uji koefisien determinasi $\left(\mathrm{R}^{2}\right)$. Hasil uji model adalah sebagai berikut:

a. Analisis Keragaman (Uji F)

Berdasarkan Tabel 16 menunjukan $F_{\text {hitung }}$ $(11,789)>F_{\text {tabel }}(2,40)$ pada $\alpha=0,01$. Hal ini berarti model regresi produksi jagung secara serentak dipengaruhi oleh variabel benih, pupuk, tenaga kerja, tingkat ketersediaan benih, ketersediaan pupuk, dan ketersediaan tenaga kerja.

b. Koefisien Determinasi $\left(\mathrm{R}^{2}\right)$

Hasil pengujian koefisien pada Tabel 16, dapat diketahui bahwa nilai $\mathrm{R}^{2}$ adalah 0,695 yang berarti bahwa variabel benih, pupuk kimia, tenaga kerja, tingkat ketersediaan benih, tingkat ketersediaan pupuk, dan tingkat ketersediaan tenaga kerja dapat menjelaskan variabel produksi sebesar $69,50 \%$ sedangkan sisanya $30,5 \%$ dijelaskan oleh variabel lain yang tidak masuk dalam model.

Untuk melihat pengaruh variabel bebas terhadap variabel dependen yaitu produksi dilakukan uji t untuk masing-masing variabel tersebut.

1) Benih

Variabel benih berpengaruh nyata terhadap produksi jagung. Hal ini ditunjukan dengan koefisien regresi sebesar 0,858 dengan tanda positif, dapat diartikan bahwa jika terdapat penambahan benih jagung sebesar $1 \%$, produksi jagung akan bertambah $0,858 \%$. Artinya di daerah penelitian pengunaan benih masih dapat ditingkatkan agar produksi meningkat.

2) Pupuk Kimia

Variabel pupuk kimia tidak tampak pengaruhnya terhadap produksi jagung, karena variabel pupuk kimia mempunyai koefisien regresi yang tidak signifikan, Nilai koefisien 
regresi pupuk kimia sebesar 0,030. Hal ini dikarenakan variasi penggunaan pupuk kimia yang hampir sama di daerah penelitian (rata-rata penggunaan pupuk kimia oleh petani responden sebesar $411 \mathrm{~kg} / \mathrm{ha}$ dengan standart deviasi sebesar 189).

\section{3) Tenaga Kerja}

Variabel tenaga kerja berpengaruh nyata terhadap produksi jagung dengan nilai koefisien regresi 0,185 bertanda positif nyata pada $\alpha=0,1$. Hal tersebut menunjukan bahwa jika tenaga kerja ditambah $1 \%$ maka produksi akan bertambah sebesar $0,185 \%$. Ini menunjukan bahwa penggunaan tenaga kerja didaerah penelitian masih bisa ditingkatkan.

\section{4) Tingkat Ketersediaan Benih}

Variabel tingkat ketersediaan benih tidak tampak pengaruhnya terhadap produksi jagung. Hal ini dikarenakan ketersediaan benih menurut jawaban petani responden hampir sama. Benih yang diperoleh petani hampir semua di tempat pembelian benih yang sama, sehingga persepsi petani tehadap ketersediaan benih menjadi hampir sama pula.
5) Tingkat Ketersediaan Pupuk Kimia

Variabel tingkat ketersediaan pupuk kimia tidak tampak pengaruhnya terhadap produksi jagung. Tingkat ketersediaan pupuk kimia menurut jawaban responden hampir sama. Hal ini dikarenakan pupuk kimia diperoleh dari tempat yang sama yaitu kios remi penjualan pupuk kimia, gapoktan, dan kelompok tani.

\section{6) Tingkat Ketersediaan Tenaga Kerja \\ Variabel tingkat ketersediaan tenaga kerja tidak tampak pengaruhnya terhadap produksi, dengan nilai koefisien regresinya adalah 0,236. Hal ini dikarenakan tenaga kerja berasal dari dalam keluarga sehingga ketersediaan tenaga kerja menurut jawaban petani hampir sama. Tenaga kerja yang berasal dari luar keluarga cukup sedikit, hanya pada saat musim tanam dan panen jagung tiba banyak tenaga kerja dari luar keluarga. \\ 3.3.2. Analisis Faktor-faktor yang Berpengaruh Pada Pendapatan Usahatani Jagung}

Hasil analisis regresi fungsi respon pendapatan disajikan pada Tabel 4.

Tabel 4. Hasil Uji Regresi Fungsi Respon Pendapatan

\begin{tabular}{llll}
\hline Variabel & Koefisien Regresi & $\mathbf{t}_{\text {hitung }}$ & Sig. \\
\hline (Constant) & $-130873,681$ & $-0,414$ & \\
Penerimaan (Rp/Ha) & $1,036^{*}$ & 44,827 & 0,000 \\
Biaya Benih (Rp/Ha) & $-1,053^{* *}$ & $-3,433$ & 0,002 \\
Biaya Pupuk (Rp/Ha) & $-0,970^{*}$ & $-24,660$ & 0,000 \\
Biaya Tenaga Kerja (Rp/Ha) & $-1,042^{*}$ & $-12,866$ & 0,000 \\
Tingkat Ketersediaan Benih (Skor) & $-17700,320$ & $-1,217$ & 0,233 \\
Tingkat Ketersediaan Pupuk (Skor) & $-21758,080$ & $-1,430$ & 0,163 \\
Tingkat Ketersediaan Tenaga Kerja (Skor) & $37076,579^{* * *}$ & 1,802 & 0,082 \\
\hline
\end{tabular}

$$
\begin{aligned}
& \mathrm{F}_{\text {hitung }}=654,905 \\
& \mathrm{R}^{2}=0,993
\end{aligned}
$$

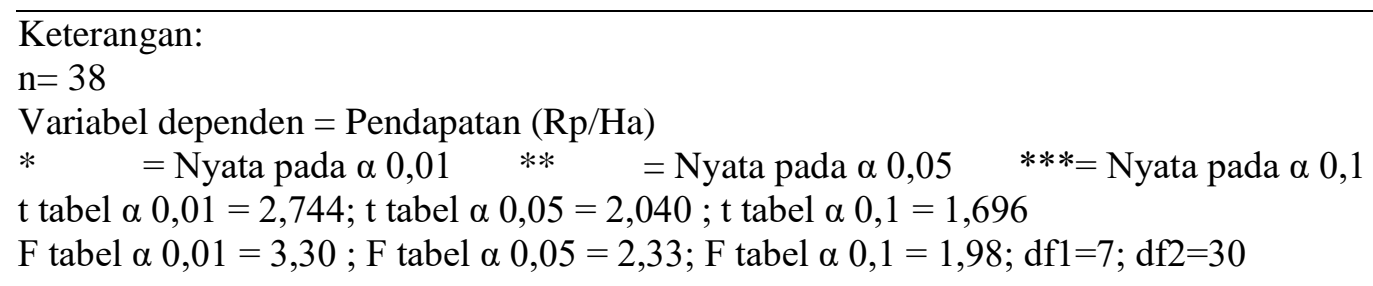

Dari hasil uji asumsi klasik dapat disimpulkan bahwa data untuk model regresi yang dipakai tidak terjadi penyimpangan terhadap asumsi klasik. Setelah uji asumsi klasik, dilanjutkan uji model menggunakan uji $\mathrm{F}$, uji koefisien determinasi $\left(\mathrm{R}^{2}\right)$. Hasil uji model adalah sebagai berikut:

\begin{abstract}
a. Analisis Keragaman (Uji F)
Tabel 18 menunjukan $F_{\text {hitung }}(654,905)>$ $\mathrm{F}_{\text {tabel }}(2,33)$ pada $\alpha=0,01$. Hal ini berarti bahwa model regresi pendapatan usahatani jagung secara bersamaan dipengaruhi oleh variabel bebasnya yaitu penerimaan, biaya benih, biaya pupuk, biaya tenaga kerja, tingkat ketersediaan benih, tingkat ketersediaan pupuk, dan tingkat ketersediaan tenaga kerja.
\end{abstract}


b. Koefisien Determinasi $\left(\mathrm{R}^{2}\right)$

Berdasarkan Tabel 18 nilai $\mathrm{R}^{2}$ adalah 0,993 atau $99,3 \%$. Hal tersebut menunjukan bahwa variabel independen yaitu biaya benih, biaya pupuk, biaya tenaga kerja, penerimaan, tingkat ketersediaan benih, tingkat ketersediaan pupuk, dan tingkat ketersediaan tenga kerja dapat menjelaskan variabel dependen (pendapatan) sebesar $99,3 \%$. Sisanya sebesar $0,7 \%$ dipengaruhi oleh model lain yang tidak masuk dalam model. Untuk melihat pengaruh variabel bebas terhadap variabel dependen yaitu pendapatan dilakukan uji $\mathrm{t}$ untuk masing-masing variabel tersebut.

1) Nilai Produksi (Penerimaan Kotor)

Penerimaan yang diperoleh hasil usahatani jagung berpengaruh nyata terhadap pendapatan usahatani jagung dengan koefisien regresi sebesar 1,036 bertanda positif pada $\alpha=0,01$. Hal tersebut menunjukan bahwa setiap penambahan penerimaan sebesar Rp 1.000,- akan meningkatkan pendapatan sebesar $\mathrm{Rp}$ 1.036,Hal ini sesuai dengan teori ekonomi dari pendapatan bahwa pendapatan dipengaruhi oleh hasil penerimaan dan total biaya yang dikeluarkan. Semakin tinggi penerimaan yang didapat maka pendapatan yang diperoleh akan naik pula. Dan penerimaan juga berkaitan dengan produksi yang diperoleh, sehingga jika produksi yang dihasilkan lebih banyak maka penerimaan yang didapat juga lebih banyak pula dengan asumsi bahwa harga jual dianggap sama.

\section{2) Biaya Benih}

Variabel biaya benih berpengaruh nyata terhadap pendapatan usahatani jagung. Ditunjukan dengan nilai koefisen regresinya sebesar 1,053 bertanda negatif pada $\alpha=0,05$, Hal ini menunjukan bahwa setiap kenaikan biaya benih sebesar $\mathrm{Rp}$ 1000,- akan menurunkan pendapatan sebesar Rp 1,053,-. Penggunaan benih di daerah penelitian masih bisa meningkatkan produksi akan tetapi bisa menurunkan pendapatan. Sehingga dalam hal ini penambahan penggunaan benih jagung harus memperhatikan harga benih yang digunakan.

\section{3) Biaya Pupuk Kimia}

Variabel biaya pupuk kimia berpengaruh nyata terhadap pendapatan usahatani jagung. Ditunjukan dengan nilai koefisien regresi sebesar 0,970 bertanda negative pada $\alpha=0,01$. Hal tersebut menunjukan bahwa setiap kenaikan biaya pupuk Rp. 1000,- akan menurunkan pendapatan sebesar Rp. 970,-.
Penambahan penggunaan pupuk kimia di daerah penelitian akan bisa menurunkan pendapatan usahatani jagung, untuk penambahan atau pengurangan input produksi perlu memperhatikan harga input produksinya khususnya harga pupuk kimia di daerah penelitian. Di daerah penelitian penggunaan biaya pembelian pupuk kimia termasuk salah satu biaya yang banyak dikeluarkan untuk usahatani jagung.

4) Biaya Tenaga Kerja

Variabel biaya tenaga kerja berpengaruh nyata terhadap pendapatan usahatani jagung dengan nilai koefisien regresi sebesar 1,042 bertanda negatif pada $\alpha=0,01$. Artinya setiap kenaikan Rp 1000,- biaya tenaga kerja akan menurunkan pendapatan sebesar Rp 1.042,-. Penambahan biaya tenaga kerja akan mengurangi pendapatan petani, sesuai dengan teori ekonomi apabila terjadi penambahan biaya akan mengurangi pendapatan dengan asumsi bahwa faktor lain dianggap tetap.

\section{5) Tingkat Ketersediaan Benih}

Variabel tingkat ketersediaan benih tidak tampak berpengaruh terhadap pendapatan usahatani jagung dengan nilai koefisien regresi sebesar -17700,320. Hal ini dikarenakan ketersediaan benih yang dilakukan petani di daerah penelitian hampir sama atau sergam. Benih yang digunakan petani diperoleh di toko atau tempat pembelian benih yang hampir sama, sehingga ketersediaan benih menurut jawaban petani responden hampir sama.

\section{6) Tingkat Ketersediaan Pupuk Kimia}

Variabel tingkat ketersediaan pupuk kimia tidak tampak berpengaruh terhadap pendapatan petani dengan nilai koefisien regresi sebesar 21758,080 . Tingkat ketersediaan pupuk menurut jawaban petani responden hampir seragam atau tidak bervariasi.

7) Tingkat Ketersediaan Tenaga Kerja

Variabel tingkat ketersediaan berpengaruh positif nyata terhadap pendapatan, dengan nilai koefisien regresi 37076,579 pada $\alpha=0,1$. Artinya setiap peningkatan $1 \%$ tingkat ketersediaan pupuk dapat meningkatkan pendapatan sebesar $37076,579 \%$. Hal ini dikarenakan tenaga kerja lebih banyak berasal dari dalam keluarga sehingga ketersediaan tenaga kerja menjadi cukup tersedia. 


\subsection{Analisis Tingkat Efisiensi Penggunaan Faktor-faktor Produksi Usahatani Jagung}

Tabel 5. Analisis Tingkat Efisiensi Pengggunaan Faktor-faktor Produksi Usahatani Jagung di Desa Ngrancang

\begin{tabular}{ccccccccc}
\hline Variabel & $\boldsymbol{b}_{\boldsymbol{i}}$ & $\mathbf{Y}$ & $\mathbf{X}$ & $\boldsymbol{P}_{\boldsymbol{X}}$ & $\boldsymbol{P M}_{\boldsymbol{X}}$ & $\boldsymbol{N P} \boldsymbol{M}_{\boldsymbol{x}}$ & $\boldsymbol{N P}_{\boldsymbol{x}} \boldsymbol{M}_{\boldsymbol{x}}$ & $\mathbf{X}^{*}$ \\
\hline Benih & 0,859 & 1978 & 5,17 & 72895 & 328,52 & 834263,63 & 11,44 & 59,18 \\
Tenaga Kerja & 0,195 & 1978 & 30 & 40000 & 13,05 & 33138,10 & 0,83 & 24 \\
\hline
\end{tabular}

Keterangan: $\mathrm{X}^{*}=$ tingkat penggunaan $\mathrm{X}$ yang optimum pada tingkat harga yang berlaku

a. Efisiensi Alokatif Penggunaan Benih

Hasil analisis penggunaan benih jagung di

Desa Ngrancang diperoleh nilai NPMx/Px sebesar 11,44. Nilai ini menunjukan bahwa alokasi penggunaan benih tersebut kurang atau terlalu sedikit sehingga perlu ditambah. Anjuran penggunaan benih dari petugas penyuluh lapang di daerah penelitian yaitu $15-20 \mathrm{~kg} / \mathrm{ha}$. Penggunaan benih rata-rata di daerah penelitian yaitu $5,17 \mathrm{~kg} / \mathrm{ha}$. Penggunaan benih yang optimal pada tingkat harga yang berlaku saat penelitian diperoleh sebesar 59,18 kg/ha. Sehingga penggunaan benih di daerah penelitian perlu ditambah.

Menurut Menegristek (2000), penggunaan benih jagung untuk setiap hektarnya sebanyak 20-30 kg. Sedangkan rata-rata penggunaan jagung di daerah penelitian masih jauh dari anjuran yaitu $5,17 \mathrm{~kg}$ per hektar. Sehingga penggunaan benih di daerah penelitian perlu penambahan agar produksi yang dihasilkan juga bertambah.

\section{b. Efisiensi Alokatif Penggunaan Tenaga Kerja}

Hasil analisis penggunaan tenaga kerja di lokasi penelitian diperoleh nilai nilai NPMx/Px sebesar 0,83. Ini menunjukan bahwa alokasi penggunaan tenaga kerja sudah berlebihan dan perlu dikurangi. Penggunaan tenaga kerja yang optimal diperoleh sebesar 24 HKSP. Sedangkan rata-rata penggunaan tenaga kerja di lokasi penelitian sebanyak 30 HKSP.

Penggunaan tenaga kerja untuk usahatani jagung yang terlalu banyak akan menyebabkan biaya yang dikeluarkan untuk upah tenaga semakin banyak pula. Penggunaan tenaga kerja perlu dikurangi sesuai dengan kebutuhan usahatani yang dilakukan. Pengurangan tenaga kerja akan juga mengurangi biaya yang dikeluarkan untuk tenaga kerja dan bisa dialokasikan untuk yang lainya.
Hasil analisis tingkat efisisensi alokatif dari rata-rata penggunaan faktor-faktor produksi pada usahatani jagung disajikan pada Tabel 5.

\section{Kesimpulan}

Berdasarkan hasil analisis penelititan yang dilakukan dapat disimpulkan bahwa:

1. Tingkat ketersediaan faktor produksi ushatani jagung (benih, pupuk, dan tenaga kerja) sudah tergolong dalam kategori cukup tersedia.

2. Tingkat produksi usahatani jagung di daerah penelitian masih tergolong rendah dibandingkan dengan tingkat produksi Kabupaten Bojonegoro. Tingkat produksi di daerah penelitian yaitu 3,9 ton/ha, sedangkan di Kabupaten Bojonegoro ratarata sebesar 4,23 ton/ha. Usahatani jagung masih layak untuk dikembangkan dengan $\mathrm{R} / \mathrm{C}$ ratio sebesar 1,6 dan pendapatan sebesar Rp 3.778.994/ha.

3. Benih dan tenaga kerja berpengaruh positif terhadap produksi. Semakin tinggi penggunaan benih dan tenaga kerja maka semakin tinggi pula tingkat produksinya. Penerimaan dan tingkat ketersediaan tenaga kerja berpengaruh positif terhadap pendapatan, sebaliknya biaya benih, biaya pupuk dan biaya tenaga kerja berpengaruh negatif.

4. Penggunaan benih pada tingkat harga berlaku di daerah penelitian belum efisien. Penggunaanya masih terlalu rendah dibandingkan yang dianjurkan PPL. Ratarata penggunaan benih sebesar $10,48 \mathrm{~kg}$ sedangkan anjuran dari PPL sebesar 15-20 kg. Penggunaan tenaga kerja pada tingkat harga yang berlaku di daerah penelitian juga sudah terlalu banyak dibandingkan dengan hasil penelitian terdahulu. Ratarata penggunaan tenaga kerja sebesar 30 HKSP (35 HOK). Sedangkan rata-rata hasil penelitian terdahulu sebesar 28 HKSP (di Kecamatan Jatiroto Kabupaten Wonogiri dan 11 HKSP (di Desa Bondosewu, Kecamatan Talun, Kabupaten Blitar). 


\section{Daftar Pustaka}

Badan Pengawas Perdagangan Berjangka Komoditi. 2012. Gudang SRG Solusi Impor Jagung. Available at http://www.bappebti.go.id/id/edu/articles/d etail/2989.html. Diakses Pada Tanggal 03 Februari 2015.

Badan Pusat Statistika Bojonegoro. 2014. Kabupaten Bojonegoro Dalam Angka 2014. Available at http://bojonegorokab.bps.go.id/?hal=publik asi detil\&id=63. Diakses Pada Tanggal 04 Februari 2015.

Cholis, Anggita Silvia. 2014. Efisiensi Penggunaan Faktor-faktor Produksi Pada Usahatani Jagung (Studi Kasus di Desa Bondosewu, Kecamatan Talun, Kabupaten Blitar. Skripsi. Universitas Brawijaya. Malang.

Dinas Pertanian Kabupaten Bojonegoro. 2015. Data Luas Lahan, Produktivitas dan Produksi Jagung 2009-2014. Kabupaten Bojonegoro.

Kementrian Pertanian. 2011. Teknologi Budidaya Jagung. Perpustakaan Nasional Katalog Dalam Terbitan (KDT). Jakarta.

Menegristek. 2000. Jagung. Proyek Pemd. Bappenas. Jakarta.

Mubyarto, 1989. Pengantar Ekonomi Pertanian Edisi Ketiga. LP3ES. Jakarta.

Parel, C.P., Caldito, G. C., Ferrer, P.L., De Guzman, G.G., Sinsloco, C.S., Tan, R.H. 1973. Sampling Design and Prosedures The Agric. Development Council Inc. New York.

Sari, Nian Tanjung. 2011. Analisis Efisiensi Ekonomi Penggunaan Faktor-faktor Produksi Pada Usahatani Jagung Varietas Bisi-2 di Kecamatan Jatiroto Kabupaten Wonogiri. Skripsi. Universitas Sebelas Maret. Surakarta.

Soekartawi. 1990. Teori Ekonomi Produksi (Pokok Bahasan Analisis Fungsi CobbDouglas). Penerbit PT. Raja Grafindo Persada. Jakarta.

Warsana. 2007. Analisis Efisiensi dan Keuntungan Usahatani Jagung (Studi di Kecamatan Randublatung Kabupaten Blora). Tesis. Universitas Diponegoro. Semarang. 